\title{
Diffuse alveolar hemorrhage as a manifestation of Behçet disease
}

\author{
V. Grosso', E. Boveri², L. Bogliolo', C. Montecucco ${ }^{1,3}$, R. Caporali ${ }^{1,3}$ \\ ${ }^{1}$ Division of Rheumatology, IRCCS Policlinico San Matteo Foundation, Pavia; \\ 2Institute of Surgical Pathology, IRCCS Policlinico San Matteo Foundation, Pavia; \\ ${ }^{3}$ University of Pavia, Italy
}

\section{SUMMARY}

Diffuse alveolar hemorrhage (DAH) is a rare life-threatening condition which refers to the presence of red blood cells within alveoli deriving from hemorrhage originating in the pulmonary microvasculature. It differs from alveolar filling, in which blood cells derive from localized bleeding, usually of bronchial origin. DAH may be part of diffuse alveolar injury of any origin.

DAH should be considered a medical emergency due to the significant morbidity and mortality associated with respiratory failure, when secondary to impaired oxygen uptake from alveoli filled with erythrocytes.

Patients with alveolar hemorrhage present with non-specific symptoms like dyspnea, cough and hemoptysis, which is not always present. They may develop acutely or insidiously over a few days.

We present a case of a patient with probable Behçet's disease complicated by pulmonary capillaritis and DAH resulting in refractory respiratory failure and death.

Key words: Alveolar hemorrhage, Behçet disease, Vasculitis.

Reumatismo, 2013; 65 (3): 138-141

\section{CASE REPORT}

A 70-years-old Caucasian male presented with multiple and painful oral ulcers involving soft palate, throat and tongue. He referred an anamnestic history of arthralgia, recurrent oral aphthosis, back acne and hemochromatosis (heterozygotes of H63D) with secondary hepatic cirrhosis. Esophago-gastro-duodenoscopy showed mild atrophic gastritis with intestinal metaplasia; ocular examinations found no evidence of uveitis.

Blood test results showed mild leukopenia and anemia; anti-nuclear antibodies (ANA), anti-exractable nuclear antigens (ENA) antibodies, anti-double stranded (ds) DNA antibodies, anti-neutrophil cytoplasmic antibodies (ANCA), anti-glomerular basement membrane antibodies, antiSaccharomyces cerevisiae antibodies, and anti-mitochondrial antibody were negative. The third (C3) and fourth (C4) component of complement levels where normal. HLAB typing showed B51 and B35. Suspecting an incomplete Behçet's disease, colchicine
$1 \mathrm{mg}$ a day and prednisone $12.5 \mathrm{mg}$ a day orally were started, with only slight improvement over 2 months.

The patient was then hospitalized for further investigations.

On admission, his temperature was $37.8^{\circ} \mathrm{C}$, respiratory rate 13 , oxygen saturation $98 \%$ on air at rest, heart rate $100 \mathrm{bpm}$ and blood pressure 150/80 mmHg. Auscultation of the chest revealed no pathological sign. Chest X-ray was normal.

Blood cell count showed mild neutrophilia and anemia. Erythrocyte sedimentation rate (ESR) was $112 \mathrm{~mm} /$ first hour and Creactive protein (CRP) $11.6 \mathrm{mg} / \mathrm{dL}$ (normal values below $15 \mathrm{~mm} / \mathrm{h}$ and $0.5 \mathrm{mg} / \mathrm{dL}$, respectively). Microbiological sampling (blood and feces cultures, throat and oral ulcers swabs) found no evidence of infection; search for Helicobacter pylori and HIV ELISA tests were negative.

Colonoscopy was delayed due to patient's inability to assume bowel preparation due to intense oral pain.

Intravenous therapy with methylprednisolone $40 \mathrm{mg}$ daily was started with initial 
healing of oral ulcers, marked reduction of pain, disappearance of fever.

After twelve days, oral ulcers were completely healed, patient's conditions were stable, with no episode of fever.

The twelfth night, cough and chills followed by fever (temperature up to $39^{\circ} \mathrm{C}$ ) appeared. After about one hour, the patient complained of chest pain and dyspnea. Blood pressure was $75 / 40$ and heart rate was $145 \mathrm{bpm}$.

Oxygen saturation on air at rest dropped to $84 \%$ and without improvement despite non-invasive ventilation with oxygen flow up to $15 \mathrm{~L} / \mathrm{min}$. At blood cell count hemoglobin was $9.8 \mathrm{mg} / \mathrm{dL}$ (with a decrease of 0.8 compared with admission) with neutrophilic leukocytosis (white blood cells $24,180 / \mu \mathrm{L})$. Chest X-ray showed right multiple patchy consolidation with pulmonary congestion. Attempt of tracheal intubation revealed presence of fresh blood in the airway. Within 4 hours, despite the institution of advanced life supports, patient's condition kept worsening and resulted in death.

Post-mortem examination found diffuse blood effusion in both lungs and pleural cavity, with a histologic pattern of interstitial edema and leak of red blood cells into the alveolar spaces in the context of pulmonary necrotizing vasculitis, involving arterioles, capillaries and venules, with neutrophilic infiltration (Fig. 1). No sign of thrombi, pulmonary artery aneurysms (PAA) or other pathologies were found, with the exception of the already known hepatic cirrhosis.

\section{DISCUSSION}

$\mathrm{DAH}$ is a rare yet serious and frequently life-threatening complication of a variety of conditions, often presenting as a catastrophic clinical syndrome causing respiratory failure, with poor outcome (1). Patients often complain of cough, dyspnea and hemoptysis, but it remains crucial to remember that even the most severe cases can lack the last one $(2,3)$. Fever, asthenia and other systemic complaints may be present, depending on the underlying disease. Most patients will have crackles on their pulmonary examination, but the physical signs are usually nonspecific. Chest X-ray may reveal patchy alveolar infiltrates starting in a focal, unilateral pattern and becoming diffuse with time. Com-

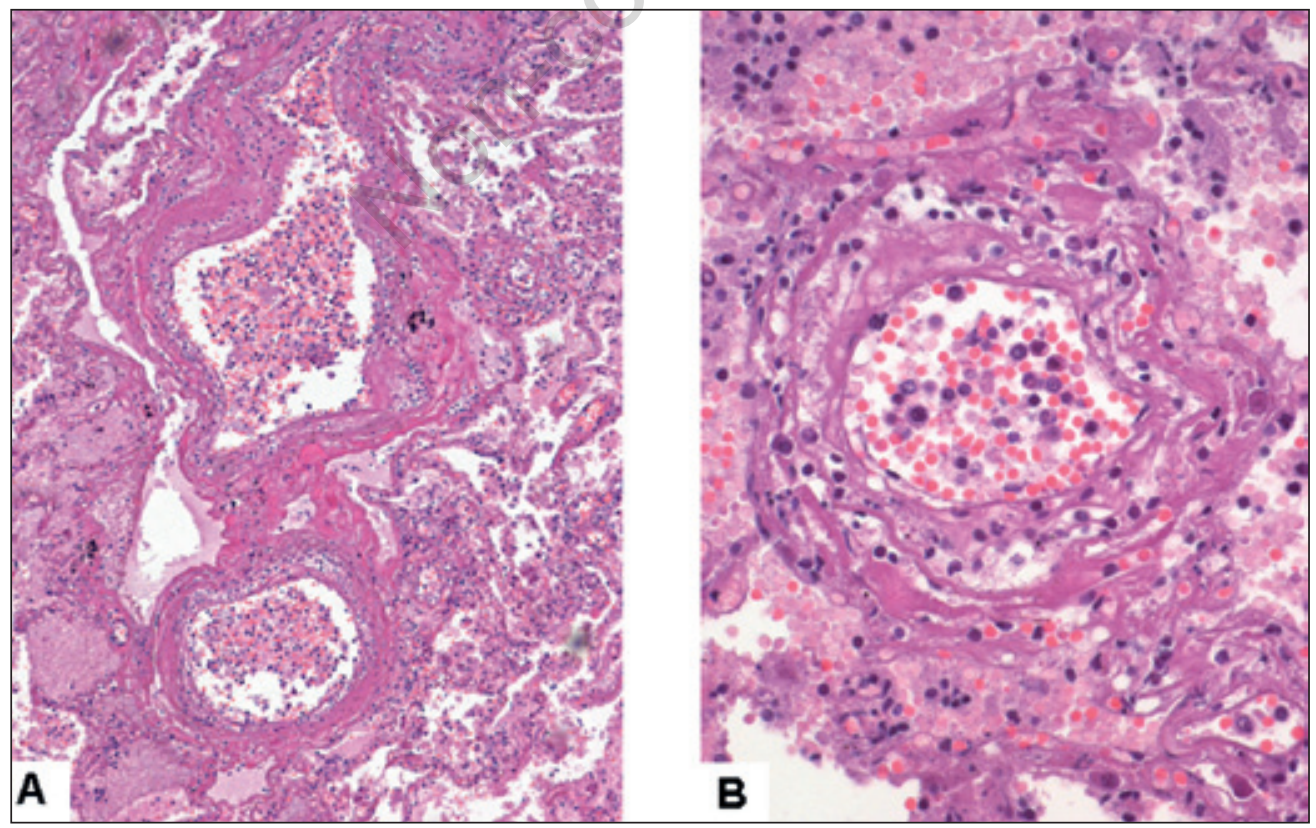

Figure 1 - Lung; the walls of medium sized vessels $(A)$ and capillaries $(B)$ showed an intense inflammatory infiltrate, mainly composed by granulocytes (Hematoxylin-Eosin, A: 20x; B: 40x). 
puted tomography scan is more specific in confirming the alveolar nature and extent of the process and may help to assess the optimal site for bronchoscopy in patients with localized manifestations (4). Most commonly, the only laboratory abnormality noted in DAH patients is anemia or decreasing hematocrit in acute presentation. In any case, clinicians should assess the renal function and look for signs suggestive of glomerulonephritis as early as possible, to rule out pulmonary-renal syndrome.

In patients who have been stabilized, the diagnostic evaluation should be done keeping in mind that, even if DAH may result from a wide range of coagulation disorders, hemodynamic conditions, drugs, toxins and infections, up to one third of the cases is caused by pulmonary capillaritis due to systemic vasculitis and autoimmune collagen vascular disease, most often ANCA-associated vasculitis and systemic lupus erythematosus. Other rheumatologic diseases, among which Henoch-Schönlein purpura, rheumatoid arthritis, scleroderma, primary antiphospholipid syndrome and
Behçet's disease may be cause of DAH. It is interesting to notice that DAH may be the first, often catastrophic, manifestation of the underlying disorder, with up to $20 \%$ of patients newly diagnosed during their intensive care unit admission (5). Therefore, clinicians should always keep in mind they might be facing the onset of a rheumatologic disorder, when a patient presents with DAH. Search for ANCA, antiglomerular basement membrane antibodies and markers of collagen vascular diseases are mandatory.

Transbronchial or open-lung biopsy may recognize three main histologic patterns: the most common one is pulmonary capillaritis with leading neutrophilic component; the second is diffuse alveolar damage; the third, uncommon, pattern consists in hemorrhage into alveolar spaces without any sign of alveolar damage (usually observed in cases with bland pulmonary hemorrhage due to anticoagulant therapy, pulmonary hypertension or Goodpasture's syndrome).

High-dose corticosteroids and cyclophos-

Table I - Reported cases of Behçet's with small vessel pulmonary vasculitis and alveolar hemorrhage, by author.

\begin{tabular}{|c|c|c|c|c|c|}
\hline Author & $\begin{array}{l}\text { Age/ } \\
\text { gender }\end{array}$ & $\begin{array}{l}\text { ISG criteria at } \\
\text { onset of alveolar } \\
\text { hemorrhage } \\
\end{array}$ & Symptoms/signs & Histology & Outcome \\
\hline Tüzün et al. (7) & $41 / \mathrm{M}$ & OU, GU & $\begin{array}{l}\text { Hemoptysis, dyspnea, } \\
\text { chest pain }\end{array}$ & $\begin{array}{l}\text { Lobular pneumonitis, intra-alveolar } \\
\text { hemorrhage, mononuclear cell } \\
\text { infiltration }\end{array}$ & $\begin{array}{l}\text { Death due to massive } \\
\text { hemoptysis }\end{array}$ \\
\hline Koga et al. (8) & $21 / F$ & OU, GU, UV & $\begin{array}{l}\text { Asymptomatic } \\
\text { pulmonary infiltrates on } \\
\text { chest x-ray }\end{array}$ & $\begin{array}{l}\text { Venulitis with mononuclear cells } \\
\text { infiltration }\end{array}$ & $\begin{array}{l}\text { Pulmonary infiltrates } \\
\text { evanesced after } \\
\text { immunosuppressive therapy }\end{array}$ \\
\hline Uzun et al. (9) & $35 / F$ & $\begin{array}{l}\text { ISG fulfilled } \\
\text { (not specified) }\end{array}$ & $\begin{array}{l}\text { Cough, hemoptysis, } \\
\text { chest pain, dyspnea, } \\
\text { sputum }\end{array}$ & Not performed & $\begin{array}{l}\text { Pulmonary infiltrates } \\
\text { evanesced after therapy with } \\
\text { colchicine }\end{array}$ \\
\hline Gamble et al. (10) & $58 / F$ & $\begin{array}{l}\text { OU (remote } \\
\text { history of UV, EN) }\end{array}$ & $\begin{array}{l}\text { Cough, fever, weight } \\
\text { loss }\end{array}$ & $\begin{array}{l}\text { Capillaritis with polymorphonuclear } \\
\text { leukocytes infiltration }\end{array}$ & $\begin{array}{l}\text { Pulmonary infiltrates } \\
\text { evanesced after high dose } \\
\text { steroid therapy }\end{array}$ \\
\hline Ota et al. (11) & $34 / \mathrm{M}$ & OU, GU, UV & Cough, fever, sputum & Necrotizing granulomatous arteritis & $\begin{array}{l}\text { Death due to pulmonary } \\
\text { thrombo-embolism and } \\
\text { massive hemorrhage }\end{array}$ \\
\hline Efthimiou et al. (12) & $25 / F$ & OU, GU, EN, PT & $\begin{array}{l}\text { Cough, hemoptysis, } \\
\text { pleuric chest pain, } \\
\text { dyspnea }\end{array}$ & $\begin{array}{l}\text { Necrotizing vasculitis (involving } \\
\text { arteries) with predominance of } \\
\text { mononuclear cells infiltration }\end{array}$ & $\begin{array}{l}\text { Death due to massive } \\
\text { hemorrhage }\end{array}$ \\
\hline Our case & 70/M & OU & $\begin{array}{l}\text { Cough, fever, dyspnea, } \\
\text { chest pain }\end{array}$ & $\begin{array}{l}\text { Necrotizing vasculitis (involving } \\
\text { arterioles, capillaries and venules) } \\
\text { with neutrophilic infiltration }\end{array}$ & $\begin{array}{l}\text { Death due to massive } \\
\text { hemorrhage }\end{array}$ \\
\hline
\end{tabular}

OU, recurrent oral ulceration; GU, recurrent genital ulceration; UV, anterior or posterior uveitis; EN, erythema nodosum; PT, positive pathergy test; ISG, International Study Group criteria for Behçet's disease. 
phamide are the leading therapy for the DAH syndrome associated with systemic vasculitis, autoimmune connective tissue diseases, Goodpasture's syndrome, and isolated pulmonary capillaritis, after infectious etiology has been ruled out. Plasmapheresis has been described as useful in several cases, but with no effects on mortality.

In this case report, the clinical course was too quick and severe to make a clear diagnosis and to start appropriate treatment. Given the presence of recurrent oral aphthosis, back acne, HLA-B51 positivity and arthralgia, high degree of suspicion remains on the diagnosis of Behçet's disease even if our patient did not fulfill the International Study Group (ISG) criteria for Behçet's disease (6).

Behçet's disease is a known, though rare, cause of alveolar hemorrhage, resulting from acute inflammatory destruction of pulmonary arteries, rupture of PAA, pulmonary infarcts, erosion of pulmonary aneurysms into adjacent bronchi or lung vessel vasculitis. Small vessel pulmonary vasculitis (arteritis, capillaritis or venulitis) causing alveolar hemorrhage was reported in 6 cases of Behçet's disease to date (Tab. I) (7-12). Clinical presentations varied from different patterns of vasculitis alone, vasculitis with thrombus formation and one case started as a pulmonary mass lesion.

Noticeably in some of these cases, this one included, pulmonary vessel disease occurred in the absence of ISG criteria of Behçet's disease (6), thus correct classification remains unclear and the diagnosis was made on the basis of an expert's opinion or with different sets of criteria.

This case illustrates the importance of a high level of clinical vigilance required to promptly suspect DAH and the difficulties related with its differential diagnosis.

Conflict of interests: the authors declare no potential conflict of interest.

Contributions: the authors contributed equally.

\section{REFERENCES}

1. Lara AR, Schwarz MI. Diffuse alveolar hemorrhage. Chest. 2010; 137: 1164-71.

2. Franks TJ, Koss MN. Pulmonary capillaritis. Curr Opin Pulm Med. 2000; 6: 430-5.

3. Green RJ, Ruoss SJ, Kraft SA, et al. Pulmonary capillaritis and alveolar hemorrhage. Update on diagnosis and management. Chest. 1996; 110: 1305-16.

4. Cordier JF, Cottin V. Alveolar hemorrhage in vasculitis: primary and secondary. Sem Resp and Crit Care Med. 2011; 32: 310-21.

5. Diaz J, Calamia KT, Lee AS. Pulmonary vasculitis in the intensive care unit. J Intensive Care Med. 2011; 26: 88-104.

6. International Study Group for Behcet's Disease. Criteria for diagnosis of Behcet's disease. Lancet. 1990; 335: 1078-80.

7. Tuzun H, Yaman M, Gemicioglu B, et al. Behcet's disease presenting with a pulmonary mass lesion. Chest. 1993; 104: 1635-6.

8. Koga T, Yano T, Ichikawa Y, et al. Pulmonary infiltrates recovered by FK506 in a patient with Behcet's disease. Chest. 1993; 104: 309-11.

9. Uzun O, Erkan L, Akpolat I, et al. Pulmonary involvement in Behcet's disease. Respiration. 2008; 75: 310-21.

10. Gamble CN, Wiesner KB, Shapiro RF, et al. The immune complex pathogenesis of glomerulonephritis and pulmonary vasculitis in Behcet's disease. Am J Med. 1979; 66: 1031-9.

11. Ota G, Nishino T, Onchi K, et al. An autopsy case of Behcet's syndrome associated with pulmonary arteritis and tuberculosis. Jpn Circ J. 1974; 38: 35-45.

12. Efthimiou J, Johnston C, Spiro SG, et al. Pulmonary disease in Behcet's syndrome. Q J Med. 1986; 58: 259-80. 